\title{
REGENERAÇÃO IN VITRO DE MILHO TROPICAL DE ALTA QUALIDADE PROTEICA
}

\author{
MARIA JOSÉ VILAÇA DE VASCONCELOS ${ }^{1}$, MARCELO ANTONIOL FONTES ${ }^{2}$, \\ CARLOS HENRIQUE SIQUEIRA DE CARVALHO ${ }^{3}$ e MAURICIO ANTONIO LOPES ${ }^{4}$
}

${ }^{1}$ Embrapa Milho e Sorgo, Caixa Postal 151- 35.701-970, Sete Lagoas, MG

mjose@cnpms.embrapa.br

${ }^{2}$ PRONEX/Embrapa Milho e Sorgo

${ }^{3}$ Embrapa Café, Varginha - MG; carlos.carvalho@embrapa.br

${ }^{4}$ Embrapa Recursos genéticos e Biotecnologia; mauricio.lopes@cenargen.embrapa.br

Revista Brasileira de Milho e Sorgo, v.8, n.2, p. 105-116 2009

RESUMO - Experimentos de transformação genética requerem protocolos ajustados de indução de calogenese e regeneração de plantas, sendo poucos os genótipos de milho tropical com a capacidade de induzir e regenerar plantas férteis e que possuem protocolos bem definidos. No presente trabalho, avaliou-se a capacidade de formação de calos embriogênicos e regeneração de plantas de nove linhagens de milho selecionadas para alta qualidade proteica (quality protein maize/QPM) e adaptadas ao clima tropical. Milhos de alta qualidade protéica são importantes para a alimentação de animais monogástricos, devido ao aumento da quantidade de alguns aminioacidos essenciais, necessários a sua dieta. Basicamente, foram utilizados meios de cultura similares àqueles propostos por Chu et al. (1975), porém, diferentes concentrações de dicamba (15 ou $30 \mu \mathrm{M})$, L-prolina (6 ou $25 \mathrm{mM})$ e nitrato de prata ( 0 ou $88 \mu \mathrm{M})$ foram testadas. Os calos formados foram classificados como dos tipos I e II. As maiores porcentagens de formação de calos embriogênicos foram obtidas no meio suplementado com $30 \mu \mathrm{M}$ de dicamba, $25 \mathrm{mM}$ de L-Prolina e $88 \mu \mathrm{M}$ de nitrato de prata, em que obtiveram-se $100 \%$ de formação de calos do tipo II, com a linhagem HGZ-A18. Os calos formados pela linhagem HGZ-A18 foram transferidos para magenta ${ }^{\mathrm{TM}}$, com quatro diferentes tipos de meios, sendo que $71,4 \%$ dos calos regeneraram plantas quando se utilizou o meio contendo sais $\mathrm{N}_{6}$ suplementado com 1,0 mg. $\mathrm{L}^{-1}$ de BAB o $0,5 \mathrm{mg} . \mathrm{L}^{-1}$ de AIB, resultando em $75 \%$ de plantas férteis em casa de vegetação.

Palavras-chave: linhagens de milho QPM, embriões imaturos, cultura de tecidos, embriogênese somática, Zea mays. 


\title{
IN VITRO REGENERATION OF TROPICAL QUALITY PROTEIN MAIZE
}

\begin{abstract}
Experiments on genetic transformation require well-defined protocols for callus induction and plant regeneration but few tropical maize genotypes are capable of inducing and regenerating fertile plants. In the present work, nine tropical maize inbred lines selected for high-quality protein were evaluated for the capacity of embryogenic calli formation and plant regeneration. High quality protein maize is an important component in monogastric animal nutrition due to the increased amounts of essential amino acids. Basically, culture media similar to those proposed by Chu et al. (1975) were used, but containing different concentrations of Dicamba $(15$ or $30 \mu \mathrm{M})$, L-proline (6 or $25 \mathrm{mM})$ and silver nitrate $(0$ or $88 \mu \mathrm{M})$. Calli produced were classified as types I and II. The highest percentage of embryogenic calli was obtained in the medium supplemented with $30 \mu \mathrm{M}$ Dicamba, $25 \mu \mathrm{M}$, L-proline and $88 \mu \mathrm{M}$ silver nitrate. The line HGZ-A18 presented $100 \%$ of type II embryogenic calli. These calli were transferred to magenta ${ }^{\mathrm{TM}}$ with four different media. This line presented $71.4 \%$ of regenerated plants when applied the medium containing $\mathrm{N}_{6}$ salts supplemented with $1.0 \mathrm{mg} . \mathrm{L}^{-1} \mathrm{BAB}$ and $0.5 \mathrm{mg} . \mathrm{L}^{-1} \mathrm{AIB}$, resulting in $75 \%$ of fertile plants in the greenhouse.
\end{abstract}

Key words: Quality protein maize lines, tissue culture, immature embryos, somatic embryogenesis, Zea mays.

Milhos de alta qualidade proteica QPM - são importantes para a alimentação de animais monogástricos, devido ao aumento da quantidade de alguns aminoácidos essenciais, necessários a sua dieta. Trabalhos com o objetivo de desenvolver protocolos de embriogênese somática e regeneração de plantas de milhos visando o seu uso na transformação genética são importantes em programas de pesquisa focados na modificação das proteínas do milho. A regeneração de plantas de milho utilizando embriões imaturos como fonte de explantes foi descrita pela primeira vez por Green \& Phillips, em 1975. Embriões com 10 a 15 dias após a fecundação das sementes, medindo aproximadamente 1,0 a 2,0 $\mathrm{mm}$ de comprimento, foram coletados e colocados em placas de Petri, com o eixo embrionário em contato com o meio, para a indução e proliferação de células do escutelo, as quais formam os calos. Essa técnica tem sido a mais comumente utilizada para a regeneração de gramíneas (Binott et al., 2008; Ombori et al., 2008; Oduor et al., 2006; Danson et al., 2006; Jedidah et al., 2006; Huang et al., 2004; ElItriby et al., 2003; Frame et al., 2002; Santos- 
Serejo \& Aguiar-Perecin, 2000; Carvalho et al., 1997; Bohorova et al., 1995).

Calos embriogênicos podem ser classificados como dos tipos I e II. Os calos do tipo I são constituídos de dois tecidos distintos: um tecido duro, compacto e amarelo ou branco, geralmente capaz de regenerar plantas; o outro é granular, amarelo-pálido ou cinza-claro, translúcido e não é capaz de regenerar plantas (Vasil \& Vasil, 1981). Já os calos classificados como do tipo II são macios, friáveis e altamente embriogênicos (Armstrong \& Green, 1985; Tomes \& Smith, 1985). As culturas formadoras de calos do tipo II crescem rapidamente, podem ser mantidas por um longo período de tempo e formam um grande número de embriões somáticos facilmente transformáveis em plantas (Vasil, 1987).

Poucas são as linhagens de milho tropical identificadas como produtoras de calos embriogênicos do tipo II e que tenham boa capacidade de regeneração in vitro, daí a necessidade de encontrar outros genótipos com essas características, para que se possa aumentar a base genética dos programas de melhoramento que usam métodos de cultivo in vitro e técnicas de transformação. Porém, com as alterações feitas na composição dos meios de cultura e também nas relações e doses dos reguladores de crescimento, juntamente com o avanço da metodologia de cultivo in vitro, tornou-se possível a regeneração de um grande número de genótipos (Prioli \& Silva, 1989; Furini \& Jewell, 1994 e 1995; Bohorova et al., 1995; Carvalho et al., 1997; Frame et al., 2002; El-Itriby et al., 2003; Danson et al., 2006; Jedidah et al., 2006; Oduor et al., 2006; Binott et al., 2008). A habilidade de regenerar plantas de milho a partir de embriões provenientes de cultura de calos tem sido relatada como dependente do genótipo usado. Diversos trabalhos já foram conduzidos para estudar o controle genético na regeneração de plantas no cultivo in vitro de várias espécies, devido à possibilidade de selecionar genótipos com alta frequência de regeneração de plantas e transferência dessa característica para genótipos superiores, mas com baixo potencial para cultivo in vitro (Sharma et al., 2005; Huang et al., 2004; Shohalel et al., 2003; Fluminhan \& Aguiar-Perecin, 1998; Prioli \& Silva, 1989; Lee \& Phillips, 1987; Hodgs et al., 1986).

Como descrito, a iniciação de calos regeneráveis em milho, bem como a frequência de regeneração de plantas são afetadas por componente genético e dependem do genótipo utilizado (Philllips et al., 1988). Além disso, várias características podem alterar a expressividade dos genes que controlam a indução da embriogênese somática e a regeneração de plantas, entre elas, pode-se destacar: o estádio de desenvolvimento e o estado fisiológico do explante no momento da excisão, interações específicas entre o genótipo e condições de cultivo da planta doadora e as estações do ano (Prioli \& Silva, 1989). Dessa forma, até as plantas ou genótipos considerados altamente recalcitrantes podem chegar à morfogênese, quando utilizados 
explantes de plantas que cresceram sob condições ótimas e que estejam em adequado estádio de desenvolvimento. De maneira inversa, plantas que geralmente produzem calos e regeneram-se facilmente in vitro podem não regenerar ou ter muita dificuldade, quando da utilização de plantas cultivadas em condições adversas ou explantes inadequados (Vasil,1987).

Este trabalho objetivou otimizar um protocolo para a formação de calos embriogênicos friáveis e regeneração de plantas de milho tropical de alta qualidade proteica (Quality Protein maize - QPM), visando o seu uso na transformação genética. Foram testadas nove linhagens e meios de cultura com diferentes níveis de prolina, nitrato de prata e dicamba, visando o ajuste de protocolo de regeneração de plantas a ser utilizado em transformação genética de milho QPM.

\section{Material e Métodos}

\section{Material genético}

Nove genótipos de milho de alta qualidade proteica (Tabela 1) pertencentes ao programa de melhoramento genético de milho para alta qualidade proteica da Embrapa Milho e Sorgo foram plantados no campo, para produção de espigas de milho como fonte de embriões imaturos, no Núcleo de Biologia Aplicada - NBA da Embrapa Milho e Sorgo, em Sete Lagoas, MG.

\section{Formação de calos e regeneração de plantas}

O procedimento usado para formação de calos e regeneração de plantas foi baseado na metodologia usada por Bohorova et al. (1999). As espigas foram coletadas 10 a 15 dias após a fecundação e desinfestadas superficialmente

TABELA 1. Linhagens de milho de alta qualidade proteica obtidas do programa de melhoramento de milho da Embrapa Milho e Sorgo, Sete Lagoas, Minas Gerais.

\begin{tabular}{ccl}
\hline Número & Genótipo & \multicolumn{1}{c}{ Origem } \\
\hline 01 & CMS 477 BC $_{4} \mathrm{~F}_{2}$ & Embrapa Milho e Sorgo \\
02 & HGZ-A 04 & Embrapa Milho e Sorgo \\
03 & HGZ-A 05 & Embrapa Milho e Sorgo \\
04 & HGZ-A 08 & Embrapa Milho e Sorgo \\
05 & HGZ-A 09 & Embrapa Milho e Sorgo \\
06 & HGZ-A 10 & Embrapa Milho e Sorgo \\
07 & HGZ-A 15 & Embrapa Milho e Sorgo \\
08 & HGZ-A 17 & Embrapa Milho e Sorgo \\
09 & HGZ-A 18 & Embrapa Milho e Sorgo \\
\hline
\end{tabular}


por imersão em 70\% de etanol, operação essa seguida de incubação, por 40 minutos, em solução de $2,5 \%$ de hipoclorito de sódio e três lavagens com água deionizada estéril. Embriões medindo aproximadamente 1,0 a $1,2 \mathrm{~mm}$ de comprimento foram extraídos de espigas de milho, com o auxílio de uma pinça, e inoculados em placas de Petri de $8 \mathrm{~cm}$ de diâmetro, com o eixo embrionário em contato com o meio de cultura. Em seguida, as placas foram incubadas à temperatura de $25 \pm 2{ }^{\circ} \mathrm{C}$, na ausência de luz, por seis semanas.

\section{Meios para cultura de tecidos}

O meio de iniciação dos calos foi formado por sais e vitaminas $\mathrm{N}_{6}$ (Chu et al. 1975), (CM-1), suplementado com 6 ou $25 \mathrm{mM}$ de prolina, 3\% (p/v) de sacarose, 100 mg.L $\mathrm{L}^{-1}$ de casaminoácido, 15 ou $30 \mu \mathrm{M}$ de dicamba e 0 ou $88 \mu \mathrm{M}$ de nitrato de prata, solidificados com phytagel $\left(1,8\right.$ g.L $\left.\mathrm{L}^{-1}\right)$ (Tabela 2A). O meio de manutenção foi o mesmo usado para a indução de calos, excetuandose o nitrato de prata (Tabela 2A). A resposta embriogênica, expressa em percentagem de formação de calos, foi analisada após 45 dias em meios de indução de calos.

\section{Meios para regeneração de plantas}

Após 42 dias, os calos embriogênicos formados foram inoculados em diferentes meios de regeneração, com variações nas concentrações de BAP (6-benzilaminopurina) e AIB (acido indol butírico). Todos os meios continham sais
MS (Mushirage e Skoog, 1962), 0.040 mg.L -1 tiamina, 0,15 g.L ${ }^{-1}$ L-asparagina, 20 g.L ${ }^{-1}$ de sacarose, $0.5 \mathrm{~mL}^{-1} \mathrm{IAA}, 1 \mathrm{~mL}$. L ${ }^{-1} \mathrm{BAP}, 100 \mathrm{mg}$. $\mathrm{L}^{-1}$ mio-inositol e $8 \mathrm{~g}$. L $\mathrm{L}^{-1}$ ágar (Tabela 2B). A regeneração das plantas foi realizada utilizandose seis magentas para cada meio, sendo que, em cada magenta, foram inoculados três setores de calos por meio de cultura (Tabela 2B). Os calos embriogênicos foram mantidos a $25 \pm 2{ }^{\circ} \mathrm{C}$, com fotoperíodo de 16 horas e intensidade luminosa em torno de $36 \mu$ moles $\mathrm{m}^{-2} \cdot \mathrm{s}^{-1}$, até a formação das plantas.

\section{Meio para enraizamento}

Após 30 dias de idade, as plantas regeneradas foram avaliadas e, então, transferidas para o meio de enraizamento (Tabela 2C). Após o processo de enraizamento, as plantas foram retiradas da condição in vitro e plantadas em vasos de plástico contendo uma mistura solo - vermiculita, na proporção 1:1. Em seguida, foram conduzidas à casa-de-vegetação, para o processo de aclimatização e obtenção de plantas adultas, sendo irrigadas conforme necessidade. Utilizou-se delineamento inteiramente casualizado, com quatro tratamentos (meios de cultivo) e seis repetições.

\section{Resultados e Discussão}

O desenvolvimento de protocolo de calogenese e regeneração de plantas de milho tropical é essencial para o desenvolvimento de um eficiente protocolo de transformação 
TABELA 2. Meios de cultura. Núcleo de Biologia Aplicada, Embrapa Milho e Sorgo, Sete Lagoas, Minas Gerais.

\section{A- Formação de calos}

\begin{tabular}{ll}
\hline Tipos de meios & Descrição dos meios de cultura \\
\hline Meio A & $\mathrm{CM}-1+25 \mathrm{mM}$ L-Proline $+15 \mu \mathrm{M}$ Dicamba $+88 \mu \mathrm{M} \mathrm{AgNO}_{3}$ \\
Meio B & $\mathrm{CM}-1+25 \mathrm{mM}$ L-Proline $+30 \mu \mathrm{M}$ Dicamba $+88 \mu \mathrm{M} \mathrm{AgNO}_{3}$ \\
Meio C & $\mathrm{CM}-1+6 \mathrm{mM}$ L-Proline $+30 \mu \mathrm{M}$ Dicamba \\
Meio D & $\mathrm{CM}-1+25 \mathrm{mM}$ L-Proline $+30 \mu \mathrm{M}$ Dicamba \\
\hline
\end{tabular}

B - Regeneração de plantas

\begin{tabular}{|c|c|}
\hline Tipos de meios & Descrição dos meios de cultura \\
\hline Meio I & Sais básicos $\mathrm{N}_{6}($ Chu et al., 1975) \\
\hline Meio II & $\begin{array}{l}\text { Sais básicos } \mathrm{N}_{6} \text {, suplementado com } 0,25 \mathrm{mg} / \mathrm{L} \text { de BAP e } 0,125 \mathrm{mg} / \mathrm{L} \text { de } \\
\text { AIB (Acido indol butírico) }\end{array}$ \\
\hline Meio III & Sais básicos $\mathrm{N}_{6}$, suplementado com $0,50 \mathrm{mg} / \mathrm{L}$ de BAP e $0,25 \mathrm{mg} / \mathrm{L}$ de AIB \\
\hline Meio IV & Sais básicos $\mathrm{N}_{6}$, suplementado com 1,0 mg/L de BAP e 0,5 mg/L de AIB. \\
\hline \multicolumn{2}{|c|}{$\mathrm{C}$ - Enraizamento } \\
\hline Tipo de meio & Descrição do meio \\
\hline
\end{tabular}

Enraizamento Sais básicos MS (Murashige e Skoog, 1962) meia força, suplementado com $1,5 \%(\mathrm{p} / \mathrm{v})$ de sacarose e $1,0 \mathrm{mg} / \mathrm{L}$ de ANA

\footnotetext{
AgNO3 - Nitrato de prata

BAP - 6-Benzilaminopurina

AIB - Ácido indol butírico
}

genética de milho. Esse processo é fundamental no desenvolvimento de plantas transgênicas para qualquer característica, independentemente se são características que afetam a produtividade, como tolerância a seca, resistência a insetos-pragas, resistência a doenças, alta qualidade proteica ou outras. Muitos laboratórios têm trabalhado nesse sentido, mas os resultados não têm sido muito promissores.
Linhagens temperadas, como a A188 (Ishida et al., 1996) ou o híbrido Hi II (Zhao et al., 1998) têm sido popularmente usadas para a transformação genética de milho temperado, não sendo próprias para o clima tropical. Armstrong et al. (1992) descreveram a existência de um gene maior ou genes no braço longo do cromossomo 9 da linhagem A188, que são responsáveis pela promoção de formação de calos embriogênicos e regeneração de plantas de milho. 
No presente trabalho, foi observada a formação de calos do tipo II e a capacidade de regenerar plantas normais de linhagens tropicais com alta qualidade proteica, plaqueando embriões imaturos de milho com 1,0 a 1,2 mm de comprimento, onde, dez a quinze dias após esse plaqueamento, foi feito o corte dos coleóptilos e os embriões recultivados em mesmo meio de cultura. As linhagems HGZ10 e HGZ-18 apresentaram a mais alta formação de calos embriogênicos quando o meio de cultura $B$ foi usado (Tabela 3). Foi observada uma intensa formação de calos embriogênicos nos embriões imaturos que foram, em parte, subcultivados em pequenos setores (meios I, II, III e IV). A percentagem de formação de calos variou de 2 a $100 \%$ nos genótipos analisados (Tabela 3). Dois tipos de calos embriogênicos foram formados, calos tipo I e tipo II. A formação destes dois tipos de calos foi descrita em milho por Jiménez \& Bangert (2001). Variações em genótipos de milho para formar calos do tipo I e II foram descritas como sendo uma característica aditiva com efeito positivo na heterose (Thomes \& Smith, 1985). A linhagem HGZ-A18 teve um excelente resultado quanto à formação de calos do tipo II na qual tanto calos embriogênicos como não embriogênicos foram detectados. Esse tipo de formação de calo também foi descrito em outros genótipos de milho (Shohael et al., 2003; Jiménez \& Bangerth, 2001) e sorgo.

Estudos têm mostrado que a idade dos embriões é um fator crítico na determinação da capacidade de iniciação de formação de calos de

TABELA 3. Formação de calos embriogênicos a partir de embriões imaturos de genótipos de milho de alta qualidade proteica, cultivados em diferentes meios de cultura. Núcleo de Biologia Aplicada, Embrapa Milho e Sorgo, Sete Lagoas, Minas Gerais.

\begin{tabular}{ccc}
\hline Número & Genótipo & $\begin{array}{c}\text { Meio B } \\
\text { Calos embriogênicos (\%) }\end{array}$ \\
\hline 01 & CMS 477 BC F $_{2}$ & 50 \\
02 & HGZ-A 04 & 03 \\
03 & HGZ-A 05 & 67 \\
04 & HGZ-A 08 & 17 \\
05 & HGZ-A 09 & 02 \\
06 & HGZ-A 10 & 100 \\
07 & HGZ-A 15 & 61 \\
08 & HGZ-A 17 & 46 \\
09 & HGZ-A 18 & 100 \\
& Média & 49,55 \\
\hline
\end{tabular}


embriões imaturos, sendo isso, provavelmente, devido à redução da atividade meristemática com envelhecimento das células, o desenvolvimento e o estádio fisiológico dos embriões são importantes na determinação da inicialização da resposta (Ombori et al., 2008). Diferentes genótipos apresentam diferenças significativas na formação de calos, isso tem sido também relatado por outros autores (Ratif et al., 2006; Bohorova et al., 1995).

A linhageHGZ-A 18, que teve excelentes resultados para a formação de calos, foi submetida aos testes de regeneração para um estudo detalhado da formação de embriões. Pequenas seções de calos foram inoculadas em meio de regeneração e, logo após a inoculação, iniciou-se o processo de enverdecimento dos mesmos em todos os meios analisados. O processo de formação de parte aérea iniciouse primeiramente no meio II, após o oitavo dia de cultivo. Nos outros meios (I, III e IV), após o décimo primeiro dia. Em todos os meios analisados, houve intensa formação de folhas (foliogênese) com alguns regenerantes desprovidos de eixo caulinar (Tabela 4). De acordo com Che et al. (2006), os calos se tornam verdes devido ao aumento da regulação de alguns genes relacionados à fotossíntese ou para outros componentes do cloroplastos. A formação de raízes ocorreu, em média, após a primeira semana em cultivo em meio de enraizamento.

Pelos resultados obtidos, verifica-se que o melhor meio de cultura para regeneração de plantas da linhagem HGZ-A18, a partir de embriões somáticos, foi o meio IV, com $71,4 \%$ de formação de regenerantes com eixo caulinar e $87,5 \%$ de formação de raízes. Os regenerantes em meio IV tiveram um índice de sobrevivência em condição ex vitro de $75 \%$. Embora nos tratamentos I, II e III, houvesse índice de regeneração superior ao

TABELA 4. Respostas morfogênicas da linhagem HGZ-A18 submetidas a diferentes meios de cultura para regeneração de plantas de milho e quantidade de plantas aclimatadas em casa-de-vegetação para cada meio utilizado. Núcleo de Biologia Aplicada, Embrapa Milho e Sorgo, Sete Lagoas, Minas Gerais.

\begin{tabular}{ccccccc}
\hline & \multicolumn{5}{c}{ Respostas morfogênicas } & Casa-de- \\
\cline { 2 - 6 } Meios & Regenerantes & $\begin{array}{c}\text { Com eixo } \\
\text { caulinar }\end{array}$ & $\begin{array}{c}\text { Sem eixo } \\
\text { caulinar }\end{array}$ & Albinos & Enraizamento & vegetação \\
\hline Meio I & $9 / 18(50,0 \%)$ & $5 / 9(55,5 \%)$ & $4 / 9(44,5 \%)$ & $1 / 9(11 \%)$ & $3 / 5(60 \%)$ & $2(40 \%)$ \\
Meio II & $11 / 18(61 \%)$ & $6 / 11(54,5 \%)$ & $5 / 11(45,5 \%)$ & $3 / 11(27,3 \%)$ & $4 / 6(67 \%)$ & $4(67 \%)$ \\
Meio III & $9 / 18(50 \%)$ & $3 / 9(33,3 \%)$ & $6 / 9(67 \%)$ & $6 / 9(67 \%)$ & $5 / 6(83 \%)$ & $4(67 \%)$ \\
Meio IV & $7 / 18(39 \%)$ & $5 / 7(71,4 \%)$ & $2 / 7(28,5 \%)$ & $2 / 7(28,5 \%)$ & $7 / 8(87,5 \%)$ & $6(75 \%)$ \\
TOTAL & $36 / 72(50 \%)$ & $19 / 36(52,8 \%)$ & $17 / 36(47,2 \%)$ & $12 / 36(33,3 \%)$ & $19 / 25(76 \%)$ & $16(64 \%)$
\end{tabular}


do tratamento IV, esses apresentaram altos índices de regenerantes sem a presença de eixo caulinar (Tabela 4), com uma média de $52,3 \%$, ao passo que, no tratamento IV, esse índice foi de $28,5 \%$. Dessa forma, podese obter, como no tratamento IV, ao final do processo de regeneração, um número maior de plantas, devendo este ser recomendado nos trabalhos de transformação genética.

A Figura 1 mostra uma visão do processo de embriogênese somática e regeneração de plantas de milho a partir de embriões imaturos da linhagem HGZ-A18, onde, na Figura 1A, há uma visão panorâmica da formação de calos embriogênicos do tipo II. A Figura 1B mostra o início da regeneração de plantas de milho HGZ-A18, a 1C, plantas em processo de aclimatação e a $1 \mathrm{D}$, plantas adultas em casa-devegetação.

\section{Conclusão}

Um sistema de formação de calo e regeneração de plantas de uma linhagem tropical de milho de alta qualidade protéica
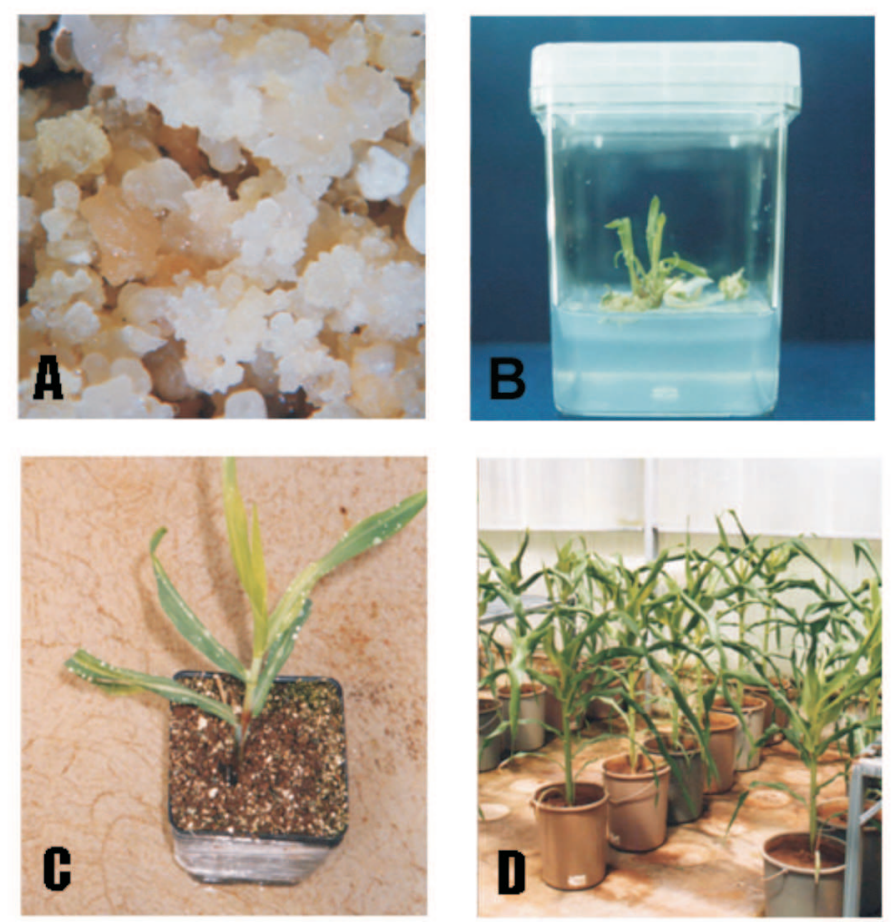

FIGURA 1. Regeneração de plantas de milho a partir de embriões imaturos da linhagem HGZ-A18. A - Calos embriogênicos, B - regeneração de plantas, C - Aclimatação e D - Plantas adultas em casade-vegetação. Núcleo de Biologia Aplicada, Embrapa Milho e Sorgo, Sete Lagoas, Minas Gerais. 
(HGZ-A18), utilizando-se embriogênese somática a partir de embriões imaturos, pode ser estabelecido, superando a limitação genotípica de milho tropical em regenerar plantas férteis, através da otimização dos meios de cultura para genótipos específicos. A otimização de um protocolo apresentado no presente trabalho, como modificação de vários meios descritos em trabalhos anteriores, foi eficiente na obtenção de plantas de milho férteis e, consequentemente, hábeis para o uso em transformação genética desse cereal tão importante para a agricultura mundial.

\section{Agradecimentos}

Marcelo Antoniol Fontes agradece ao PRONEX à concessão de sua bolsa de DTI.

\section{Literatura Citada}

ARMSTRONG, C. L.; GREEN, C. E. Establishment and maintenance of friable, embryogenic maize callus and the involvement of L- proline. Planta, New York, v. 164, p. 207 214, 1985.

ARMSTRONG, C. L.; ROMERO-SEVERSON, J.; HODGES, T. K. Improved tissue culture response of an elite maize inbred through back cross breeding and identification of chromosomal regions important for regeneration by RFLP analysis. Theoretical and Applied Genetics, Berlin, v. 84, n. 6, p. 755-762, 1992.

BINOTT, J. J.; SONGA, J. M.; ININD, J.; NJAGI, E. M.; MACHUKA, J. Plant regeneration from immature embryos of Kenyan maize inbred lines and their respective single cross hybrids through somatic embryogenesis. African Journal of Biotechnology, Grahamstown, v. 7, n. 8, p. 981987, 2008.

BOHOROVA, N. E.; LUNA, B.; BRITO, R. M.; HUERTA, L. A. HOISINGTON, D. A. Regeneration potential of tropical, subtropical, midaltitude, and highland maize inbred. Maydica, Bergamo, v. 40, p. 275-281, 1995.

BOHOROVA, N. E.; FENELL, S.; MALEAN, S.; PELLEGRINESCHI, A.; HOISINGTON, D. E. Laboratory protocols: CIMMYT Applied Genetic Engineering Laboratory. Mexico D.F.: CIMMYT, 1999. Paginação irregular.

CARVALHO, C. H. S.; BOHOROVA, N. E.; BORDALO, P. N.;ABREU, L. L.; VALICENTE, F. H.; BRESSAN, W.; PAIVA, E. Type II callus production and plant regeneration in tropical maize genotype. Plant Cell Reports, Berlin, v. 17, p. 73-76, 1997.

CHE, P.; LOVE, T. M.; FRAME, B. R.; WANG, K.; CARRIQUIRY, A. L.; HOWELL, S. H. Gene expression patterns during somatic embryo development and germination in maize Hi II callus culture. Plant Molecular Biology, Dordrecht, v. 62, n. 1, p. 1-14, 2006

CHU, C. C.; WANG, C. C.; SUN, C. S.; HSU, C.; YIN, K. C.; CHU, C. Y.; BI, F. Y. Establishment of na efficient medium for anther culture of rice through comparative experiments on the nitrogen sources. Scientia Sinica, Peking, v. 18, p. 659-668, 1975.

DANSON, W. J.; LEGAT, M.; MBOGORI, M. Screening tropical maize lines for production and regeneration of friable and embryogenic type II 
callus. African Journal of Biotechnology, Grahamstown, v. 5, n. 23, p. 2367-2370, 2006.

EL-ITRIBY, A. H.; ASSEM, S. K.; HUSSEIN, E. H. A.; ABDEL-GALIL, F. M.; MADKOUR, M. A Regeneration and transformation of Egyptian maize inbred lines via immature embryo culture and biolistic particle delivery system. In Vitro - Cellular and Development Biology, New York, v. 39, p. 524-531, 2003.

FRAME, B. R.; SHOU, H.; CHIKWAMBA, R. K.; ZHANG, Z.; XIANG, C.; FONGER, T. M.; GREEN, C. E.; PHILLIPS, R. L. Plant regeneration from tissue culture of maize. Crop Science, Madison, v. 15, p. 417-421, 2002.

FURINI, A.; JEWELL, D. C. Somatic embryogenesis and plant regeneration from immature and mature embryos of tropical and subtropical Zea mays L. genotypes. Maydica, Bergamo, v. 39, p. 155-164, 1994.

FLUMINHAN, A.; AGUIAR-PERECIN M. L. R. Embriogenic response and mitotic instability in callus cultures derived from maize inbred lines differing in heterochromatic knob content of chromosomes. Annals of Botany, Oxford, v. 82, p. 569-576, 1998.

GREEN, C. E.; PHILlIPS, R. L. Plant regeneration from tissue cultures of maize. Crop Science, Madison, v. 15, p. 417-421, 1975.

HUANG, X. Q.; WEI, Z. M. High-frequency plant regeneration through callus iniciation from immature embryos of maize (Zea mays L.). Plant Cell Reports, Berlin, v. 22, p. 293-800, 2004.
ISHIDA, V.; SAITO, H.; OHTA, S.; HIEI, Y.; KOMARI, T.; KUMASHIRO, T. High efficiency transformation of maize (Zea mays L.) mediated by Agrobacterium tumefaciens. Nature Biotechnology, New York, v. 14, p. 745-750, 1996.

JIMÉNEZ, V. M..; BANGERTH F. Hormonal status of maize initial explants and of the embriogenic and non-embryogenic callus culture derived from them as related to morphogenesis in vitro. Plant Science, Limerick, v.160, n. 2, p. 247-257, 2001.

LEE, M.; PHILLIPS, R.L. Genomic rearrangements in maize induced by tissue culture. Genome, Toronto, v. 29, p.122-128, 1987.

JEDIDAH, W. D.; LAGAT, M. K.; MBOGORI, M. Screening tropical maize lines for the production and regeneration of friable and embryogenic type II callus. African Journal of Biotechnology, Grahamstown, v. 5, p. 2367 2370, 2006.

MURASHIGE, T.; SKOOG, F. A revised medium for rapid growth and bioassay with tobacco tissue culture. Physiologia Plantarum, Copenhagen, v. 15, p. 473-497, 1962.

ODUOR, R. O.; NJAGI, E. N. M.; NDUNGU, J. $\mathrm{S}$. In vitro regeneration of dryland Kenyan maize genorypes throught somatic embryogenesis. International Journal of Botany, Oxford, v. 40, p. 146-151, 2006.

OMBORI, O.; GITONGA, N. M.; MACHUKA, J. Somatic embriogenesis and plant regeneration from immature embryos of tropical maize (Zea Mays L.) inbred lines. 
Biotechnology, Falsalabad, v. 7, n. 2, p. 224232, 2008.

PRIOLI, L. M., SILVA, W. J. Somatic embryogenesis and plant regeneration capacity in tropical maize inbreds. Brazilian Journal of Genetics, Ribeirão Preto, v. 12, p. 553-566, 1989.

RATIF, M.; FATMA, T.; BASHIR, K.; KAN, M. A.; RIAZUDDIN S. Regeneration and transformation of elite inbred lines of maize (Zea mays L.), with a gene from Baccillus thuringiensis. South African Journal Botany, Grahamstown, v.72, n. 4, p. 460-466, 2006.

SANTOS-SEREJO, J. A.; AGUIAR PERECIN, M. L. R Genotypes with high somatic embryogenesis and plant regeneration capacity obtained from tissue culture. Scientia Agricola, Piracicaba, v. 57, n. 4, p. 717-722, 2000.

SHARMA, V. K.; HANSCH, R.; MENDEL, R. R.; SCHULZE, J. Seasonal effect on tissue culture response and plant regeneration frequency from non-bombarded immature scutella of barley (Hordeum vulgare) harvested from controlled environment. Plant Cell Tissue Culture, Dordrecht, v. 81, p. 19-26, 2005.

SHOHALEL, A. M.; AKANDA, M. A. L.; PARVEZ, S.; MAHFUJA, S.; ALAM, M. F.; ISLAM, R.; JPARDER, N. Somatic embryogenesis and plant regeneration from immature embryo derived callus of inbred maize (Zea mays L.) Biotechnology, New York, v. 2, n. 2, p. 154-161, 2003.

TOMES, D. T.; SMITH, O. S. The effect of parental genotype on initiation of embryogenic callus from elite maize (Zea mays L.) germplasm. Theoretical and Applied Genetics, Berlin, v. 70, p. 505-509, 1985.

VASIL, I. K. Developing cell and tissue culture systems of the improvement of cereal and grass crops. Journal of Plant Physiology, Stuttgart, v. 128, p. 193-218, 1987.

VASIL, V.; VASIL, I. K. Somatic embryogenesis and plant regeneration from tissue cultures of Pennisetum americanum and $P$. americanum $\mathrm{X} P$. purpureum hybrid. American Journal of Botany, Bronx, v. 68, p. 864-872, 1981.

ZHAO, Z. Y.; GU, W.; CAI, T.; TAGLIANI, L. A.; BOND, D.; KRELL, S.; RUDERT, M. L.; BRUCE, W. B.; PIERCE, D. A. Molecular analysis of T0 plants trnsformed by Agrobacterium and comparison of Agrobacterium mediated transformation with bombardment transformation in maize. Maize Genetics Cooperation Newsletter, Columbia, v. 72 , p. $34-37,1998$ 